\title{
Cause and Management of Hamstring Injuries in College Sprinters - A Qualitative Approach
}

Amir Junaid Shah ${ }^{1^{*}}$ and Muhammad Talha Iftakhar ${ }^{2}$

${ }^{1}$ Aitchison College Lahore, Punjab, Pakistan

${ }^{2}$ Government Degree College Satellite Town Gujranwala, Punjab, Pakistan

*Corresponding author: Amir Junaid Shah, Aitchison College Lahore, Punjab, Pakistan, Tel: +923329733797; E-mail: amirjunaidshah@gmail.com

Received date: June 03, 2017; Accepted date: July 31, 2017; Published date: August 10, 2017

Copyright: (c) 2017 Shah AJ, et al. This is an open-access article distributed under the terms of the Creative Commons Attribution License, which permits unrestricted use, distribution and reproduction in any medium, provided the original author and source are credited.

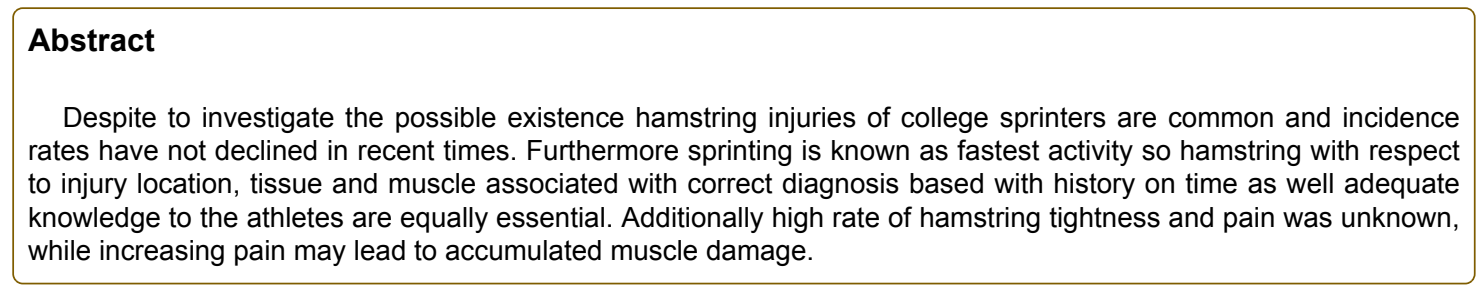

Keywords: Hamstring injuries; Athletes; Causes; Management

\section{Introduction}

Athletics refer to the development and maintenance physical health and fitness [1]. Sprinters put extreme pressure on the body that has been a risk especially on hamstring muscles in higher degree of overlapping [2]. Hamstring injuries are the most prevalent time-loss injuries in sprinting [3]. In spite of unclear understanding between thigh and hamstring muscles especially flexion of knee and hip extension may cause to a small part or organ to hamstring incidence [4]. In the competitive sprinting the gait cycle during swing phase mostly occurred hamstring strain [5]. As preview to relate literature hamstring injuries are in same condition and that certain types of injuries need prolonged rehabilitation and return to play [6]. In some condition minor injury those involving central tendencies require prolonged time to return to track [7]. The etiology of pain in emerging sprinters is usually significantly different from adults however potential causes of hamstring muscle tissue include muscle strains, muscle spasm, muscle weakness and muscle imbalances [8]. These have been identified as the primary cause of the pain which the most sprinters has faced Drawer S and Fuller CW [9] Propensity for osteoarthritis and lower limb joint pain in retired professional soccer players.

\section{Management of Injuries}

According to literature the mostly sprinters has focused on their fitness level during development phase [10], but mostly in that time when athletes efforts on skills preparation and don't concentration on muscle strengthen make a great deal to muscle damage [11]. To ignore the athlete conditioning session at such a vital time may lead to injuries in upcoming competitive phase [12]. The management goals when treating hamstring injuries are to achieve maximal reduction in pain intensity as quickly as possible, to rehabilitate every individual's muscle pain [13], to function your body for everyday activities, to facilitate the injured passage through the legal impediments rehabilitation [14]. In current phenomena of sprint demand the condition of muscle ability need to try several treatment to determine what work best for them [15]. Only a minority of hamstring injured athletes require [16] (Table $1)$.

\begin{tabular}{|l|l|}
\hline \multicolumn{1}{|c|}{ Components of fitness } & \multicolumn{1}{c|}{ Sample of eercises } \\
\hline Warm up & Dynamic movement, running forward, coordination exercise, moderate intensity sprints \\
\hline Strength & Dumble free weights, leg curve, back lunges, bend exercise \\
\hline Aerobics & Low intensity treadmill, cycling, sprint and interval training \\
\hline Core stability & Use of medicine ball, motor control exercises \\
\hline Flexibility & stretch hip flexors, hamstring, calf stretch \\
\hline Power & Vertical jumps, bounding ladder drills, barrier jumps \\
\hline Cool down & Light jogging, static stretching \\
\hline
\end{tabular}

Table 1: Exercise classification based upon component of fitness. 
In the current prospective study 41 male college sprinters of Khyber Pakhtunkhwa were followed during participation in 2nd U-23 Games at Peshawar. The criteria of current study approach was based on systematic reviews, randomized trials, classical studies and metaanalysis to propose the theme.

\section{Conclusion}

A very large number of protective methods have been introduced, to reduce muscle injuries. In some past couple of years ago there was a significant addition to the literature; however we have still not managed to decrease the incidence of hamstring muscle injuries. The major objective of the study was to view the strategies adopted by sprinters to reduce the muscle injuries. After careful analysis, the researcher despite that a very large number of college sprinters give negative initiatives regarding muscle knowledge, guideline, training session for strengthen a well researcher can be concluded that majority of the college sprinters have no idea regarding proper warm up and cool down techniques which can increase the ratio of injuries in sprinting.

\section{Recommendation}

1. Strength training will be beneficial for hamstring muscles which may help to reduce scare of muscle.

2. Proper warm up and cool down technique help an athletes for preventing from injuries.

3. Coaches compile proper strength and conditioning session and implemented on athlete.

4. Adequate nutrition helpful in prevention from muscle injuries.

\section{References}

1. Garber CE, Blissmer B, Deschenes MR, Franklin BA, Lamonte MJ, et al. (2011) Quantity and quality of exercise for developing and maintaining cardiorespiratory, musculoskeletal, and neuromotor fitness in apparently healthy adults: guidance for prescribing exercise. Med Sci Sports Exerc 43: 1334-1359.

2. Valle X, Tol JL, Hamilton B, Rodas G, Malliaras P, et al. (2015) Hamstring muscle injuries, a rehabilitation protocol purpose. Asian J Sports Med 6: e25411.
3. Petersen J, Thorborg K, Nielsen MB, Budtz-Jorgensen E, Holmich P (2011) Preventive effect of eccentric training on acute hamstring injuries in men's soccer a cluster-randomized controlled trial. Am J Sports Med 39: 2296-2303.

4. Bloomquist E (1996) Effect of thirty second static stretch on hamstring muscle flexibility in subjects over age 65 .

5. Heiderscheit BC, Hoerth DM, Chumanov ES, Swanson SC, Thelen BJ et al. (2005) Identifying the time of occurrence of a hamstring strain injury during treadmill running: A case study. Clin Biomech 20: 1072-1078.

6. Woods C, Hawkins RD, Maltby S, Huse M, Thomas A, et al. (2004) The football association medical research programme: An audit of injuries in professional football-analysis of hamstring injuries. Br J Sports Med 38: 36-41.

7. Askling CM, Tengvar M, Saartok T, Thorstensson A (2007) Acute firsttime hamstring strains during high-speed running a longitudinal study including clinical and magnetic resonance imaging findings. Am J Sports Med 35: 197-206.

8. Alter MJ (2004) Science of flexibility (3rd edn.). Human Kinetics.

9. Drawer S, Fuller CW (2001) Propensity for osteoarthritis and lower limb joint pain in retired professional soccer players. Br J Sports Med 35: 402-408.

10. Haugen T, Tonnessen E, Hisdal J, Seiler S (2014) The role and development of sprinting speed in soccer. Int J Sports Physiol Perform 9: 432-441.

11. Bompa T, Buzzichelli C (2015) Periodization training for sports (3rd edn.). Human Kinetics.

12. Gabbett TJ (2010) The development and application of an injury prediction model for noncontact, soft-tissue injuries in elite collision sport athletes. J Strength Cond Res 24: 2593-2603.

13. Petersen J, Holmich P (2005) Evidence based prevention of hamstring injuries in sport. Br J Sports Med 39: 319-323.

14. Sherry MA, Johnston TS, Heiderscheit BC (2015) Rehabilitation of acute hamstring strain injuries. Clin Sports Med 34: 263-284.

15. Kenney WL, Wilmore J, Costill D (2015) Physiology of sport and exercise. Human Kinetics.

16. Paluska SA (2005) An overview of hip injuries in running. Sports Medicine 35: 991-1014. 